\title{
India since independence
}

SIR-In your leading article "Defining half a global problem" (Nature 327, 1; 1987 ) you say about poverty that "the only saving grace is that some among [the poor] (India in the past two decades, for example) occasionally break out of this depressing mould and find a way of managing their affairs constructively. If in the process of becoming semi-rich they think it necessary to cut down a few hundred hectares (or square kilometres) of primeval rain-forest, it will be found that local people are less regretful than Ms Bruntland."

Like many of my countrymen, you have fallen for the rhetoric perpetuated by both the government and our so-called intelligentsia (of which scientists are a part) that India has made great strides since independence. A cursory glance at the achievements of China and India since independence reveals vast disparities in their achievements, whether per capita income, agriculture, science, education or health. Both countries started with similar problems at independence in the late 1940s. China, despite being cut off from the rest of the world and threatened by Japan, the United States and the Soviet Union, has been able to surpass India in almost all fields even though India has had free access to scientific development elsewhere in the world and has received large sums in foreign aid denied to its neighbour.

It would be more appropriate to compare the achievements of India with those of China rather than the rest of the developing world. The capitalist West, because of its morbid fear of communism, would like the developing countries to look up to India as the model for 'freedom' and 'democracy'. Unfortunately 'freedom' has meant only freedom for a few to exploit and the rest to starve; for contractors to be permitted to decimate our forests; for business and industry to exploit the worker who produces goods consumed by only the upper two deciles. The process has meant inhuman living conditions in urban slums to which the neglected rural section, half of whom live below the poverty line, are forced to migrate. The best scientists and doctors, trained at public expense, emigrate to the West, or if they stay in India or return home, expect scarce resources to be diverted to the building of expensive laboratories and hospitals whose output in science and health not only leaves much to be desired but is often only a caricature of their Western counterparts whom they seek to emulate.

A market economy based almost entirely on human greed and devoid of state (let alone moral) controls has polarized the country's society and its economy and sundered its fabric. Science and technology, instead of achieving its potential for rejuvenating our society, has only pandered to the personal needs of those who control it and has been used more as a tool for exploitation than for development, under whose guise most sins are committed. One can only hope that China with its new-found 'freedom' does not follow suit.

Foundation for Medical Research,

84-A RG Thadani Marg,

Worli,

Bombay-400 018, India

\section{Scientific truth}

SIR-When one agrees with the premises and conclusions of an article it is tempting not to rock the boat about the reasoning used. There are very good reasons why twentieth century philosophy of science, under the malign influence of Popper through to Feyerabend, is profoundly hostile to science itself ${ }^{1}$, as Theocharis and Psimopoulos (Nature 329, 595; 1987) correctly recognize. It is indeed unfortunate that many scientists, through ignorance, quote these philosophers approvingly. The most effective victories are those in which the losers unwittingly assist their opponents. But to suggest that the downgrading of science by philosophers is largely responsible for its loss of prestige (and consequently funding) is to overestimate the influence of philosophy. It is far more likely that stronger causes are the visible consequences of science's misapplication: nuclear weapons, pollution and so on, together with the unfulfilment of the simplistic expectation that science 'can solve all our problems'. Similarly, it is not the views of philosophers that are science's worst enemy, but the proliferation of new age and fundamentalist cults, such as creationism, iridology and crystal therapy, that have no foundation in fact.

Theocharis and Psimopoulos, in common with their opponents, regret the inability to define the 'scientific method'. But it does not matter: science attained its present level without such self-analysis, and there is no reason to suppose it cannot continue without it. Philosophy of science would become valuable to scientists only if it were able to provide a systematic replacement for the intuitive 'leap in the dark' involved in all discoveries. There are few less likely prospects than the formularization of intuition.

Nor is 'scientific truth' defined, even though it is defended against Kuhn's view that competing theories come and go as arbitrarily as fashions ${ }^{2}$. What Kuhn mystifyingly refuses to perceive is that the direction of change is not random, but is always towards better predictability: relativity predicts the outcome of dynamical events more accurately than the newtonian view it succeeded, for example. This process of making ever better predictions is scientific progress, and it circumvents entirely the problem of defining scientific truth.

AnTHONY GarRetT

School of Physics,

University of Sydney,

Sydney, NSW 2006,

Australia

Stove, D.C. Popper and After: Four Modern Irrationalists (Pergamon, Oxford, 1982)

2. Kuhn, T.S. The Structure of Scientific Revolutions, 2nd Edn (University of Chicago Press, 1970).

SIR-Theocharis and Psimopoulos ${ }^{1}$ miss the essential point when they state, under the sub-heading methodology, that the hapless student will have recourse to such (unreliable) things as random guess, arbitrary conjecture, subjective hunch, casual intuition, raw instinct, crude imagination and pure chance. Can this, they ask, be an adequate methodology by means of which to make new discoveries and beneficial applications? The history of most major break-throughs in scientific knowledge shows that it is.

Indeed, it is the element of surprise, the total negation of clear step-by-step logical thinking, that enables one's patent attorney legally to establish an inventive step when claiming patent protection; a step clearly set down for example in the European Patent Convention ${ }^{1}$ where it states in Article 56: "An invention shall be considered as involving an inventive step if, having regard to the state of the art, it is not obvious to a person skilled in the art."

43 Emanuel House,

Frank W. Cousins

18 Rochester Row,

London SW1 1BS, UK

1. Convention on the Grant of European Patents 3rd edn (European Patent Office, Wila, Munich, 1985).

\section{Colour blind}

SiR-It seems that your reviewer of Journal of Enzyme Inhibition (Nature 329, 376 ; 1987) missed the point about colour illustrations that appear in this (and most other) Harwood and Gordon and Breach journals.

The colour plates are printed separately and inserted; a black and white reproduction is integrated into the text as a reference only (the legend points to the colour original). Sometimes the black and white plate, coming from a colour original, does not show appropriate contrast. But this is nothing to do with the paper quality, which will reproduce good contrast black and white original photographs well. Neither is it critical, as the full detail necessary appears in the colour plates.

JoHn GILLMAN

Harwood Academic Publishers GmbH, PO Box 197

London WC2E 9PX, UK 